\begin{tabular}{|c|c|c|}
\hline $\begin{array}{l}\text { JURNAL } \\
\text { INOVASI } \\
\text { TEKNOLOGI } \\
\text { PENDIDIKAN }\end{array}$ & $\begin{array}{l}\text { Jurnal Inovasi Teknologi Pendidikan } \\
\text { Volume 4, No 2, October } 2017 \text { (227-237) } \\
\text { Online: http:/ /journal.uny.ac.id/index.php/jitp }\end{array}$ & $\begin{array}{l}\text { Ikatan Profesi Teknologi } \\
\text { Pendidikan Indonesia }\end{array}$ \\
\hline
\end{tabular}

\title{
PENINGKATKAN INTERAKTIVITAS PEMBELAJARAN MELALUI PENGGUNAAN KOMUNIKASI ASYNCHRONOUS DI UNIVERSITAS NEGERI YOGYAKARTA
}

\author{
Dian Wahyuningsih, Sungkono \\ 1,2)Fakultas Ilmu Pendidikan, Universitas Negeri Yogyakarta \\ dianw@uny.ac.id, sungkono@uny.ac.id
}

\begin{abstract}
Abstrak
Penelitian ini bertujuan untuk meningkatkan interaktivitas pembelajaran melalui penggunaan komunikasi asynchronous di Universitas Negeri Yogyakarta. Penelitian tindakan kelas ini dilaksanakan dalam dua siklus. Subjek penelitian ini adalah 32 orang mahasiswa Program Studi Teknologi Pendidikan UNY, yang menempuh mata kuliah Pengembangan Elearning Berbasis Web pada tahun ajaran 2015/2016. Data dikumpulkan menggunakan teknik wawancara, check list, dan dokumentasi, serta dianalisis secara deskriptif melalui teknik persentase. Hasil penelitian menunjukkan bahwa meningkatkan interaktivitas pembelajaran melalui penggunaan komukasi asynchronous pada mata kuliah pengembangan e-learning berbasis web di Prodi TP UNY dilakukan melalui 4 hal bahwa komunikasi asynchronous: (1) diterapkan secara konsisten pada mata kuliah e-Learning Berbasis Web, (2) digunakan menancap (embed) pada e-Learning UNY (Besmart), (3) dimanfaatan untuk menyelesaikan tugas yang memerlukan kolaborasi, dan (4) menggunakan tipe yang bervariasi. Interaktivitas pembelajaran mahasiswa sebelum diterapkan komunikasi asynchronous berada di kategori sangat rendah dengan persentase $35 \%$. Terjadi peningkatan interaktivitas pembelajaran mahasiswa setelah diterapkan komunikasi asynchronous di siklus pertama pada kategori rendah dengan persentase $60 \%$, dan kembali meningkat di siklus kedua pada kategori sangat tinggi dengan persentase $82,33 \%$.
\end{abstract}

Kata kunci: interaktivitas pembelajaran, komunikasi asynchronous

\section{IMPROVING LEARNING INTERACTIVITY BY IMPLEMENTING ASYNCHRONOUS COMMUNICATION IN YOGYAKARTA STATE UNIVERSITY}

\author{
Dian Wahyuningsih, Sungkono \\ 1,2)Fakultas Ilmu Pendidikan, Universitas Negeri Yogyakarta \\ dianw@uny.ac.id,sungkono@uny.ac.id
}

\begin{abstract}
This research aims to improve learning interactivity by asynchronous communication in web based e-learning development course. This study used a classroom action research (CAR) which is conducted in two cycles. The subjects were 32 students of Curriculum and Educational Technology Department Yogyakarat State University (YSU) who participated in the web based e-learning development course in academic year 2015/2016. The data were collected using percentage method by interview, check list and documentation. The result shows that, improving instructional interactivity by asynchronous communication in web based e-learning development course were conducted using four strategies, i.e: 1) asynchronous communication applied consistently on Web-based e-Learning courses, 2) embedding on e-Learning of Yogyakarta State University (Besmart), 3) utilized for completion of tasks that require collaboration, and 4) using a varied type of asynchronous mode. Learning interactivity was reach $35 \%$ in a very low category before asynchronous communication were implemented. The result shows in the $1^{\text {st }}$ cycle, instructional interactivity rose up to $60 \%$ in a low category. In the $2^{\text {nd }}$ cycle, it provides dramatically improvement up to $82,33 \%$ in very high category.
\end{abstract}

Keywords: instructional interactivity, asynchronous communication 


\section{Pendahuluan}

Informasi merupakan komponen utama dalam proses komunikasi yang mempengaruhi hubungan atar manusia di setiap interaksinya. Makmur (2016, p. 1) menjelaskan saat ini informasi ibarat emas, siapa yang memegang informasi dialah yang menjadi pemenang. Tak terkecuali dalam bidang pendidikan, penyebaran informasi pembelajaran dewasa ini banyak dilakukan menggunakan media digital atau populer disebut dengan istilah new media. New media adalah media yang berkembang pada era komunikasi interaktif, dimana pesan $\mathrm{d}$ isampaikan dalam bentuk digital melalui komputer atau jaringan teknologi informasi dan komunikasi. Badan Pusat Statistik (Maulana, 2015) menjelaskan bahwa pengguna internet di Indonesia pada tahun 2014 telah mencapai angka 88,1 juta. Hal ini mengalami pertumbuhan 16,2 juta jiwa dari total 71,9 juta pengguna di tahun 2013.

Dari data tersebut mengindikasikan bahwa masyarakat Indonesia mulai paham akan terknologi informasi dan komunikasi. Dalam bidang pendidikan khususnya pembelajaran, komputer dan internet dimanfaatkan dalam bentuk pembelajaran online. Semula pembelajaran online digunakan untuk memfasilitasi pembelajaran jarak jauh. Akan tetapi, karena kebutuhan belajar manusia modern yang menginginkan dapat belajar dengan lebih baik, cepat dan banyak maka pembelajaran online diadopsi dalam kelas tatap muka. Pemanfaatan pembelajaran online dalam dunia pendidikan populer disebut sebagai e-learning atau pembelajaran elektronik. Khan (2005) menjelaskan e-learning sendiri diartikan sebagai pengiriman materi pada siapapun, kapanpun, di manapun dengan menggunakan berbagai teknologi dalam lingkungan pembelajaran yang terbuka, fleksibel, dan terdistribusi. Lebih lanjut Surjono (2013, p. 3) menjelaskan pembelajaran terbuka dan fleksibel merujuk pada kebebasan peserta didik dalam hal waktu, tempat, kecepatan, isi materi, gaya belajar, jenis evaluasi, belajar kolaborasi atau mandiri.
E-learning sendiri memiliki beberapa manfaat seperti yang dijelaskan Rosenberg (2001, pp. 30-31) diantaranya informasi dapat disampaikan secara utuh atau disesuaikan dengan kebutuhan, konten dapat diupdate setiap waktu sehingga dapat digunakan dalam waktu yang relatif lama, pembelajaran terjadi secara fleksibel "just in time - any time", bersifat universality dan scalability, serta builds community. Walaupun e-learning memiliki banyak manfaat, namun penggunaanya belum optimal dalam pembelajaran. Dari pengamatan di lapangan, pada umumnya e-learning saat ini masih dimanfaatkan sebatas sebagai complement (pelengkap) dan supplement (tambahan) saja dalam pembelajaran, kecuali pada Universitas Terbuka yang mulai memanfaatkan e-learning sebagai replacement (pengganti) pembelajaran tatap muka atau konvensional.

E-learning menjadi kurang optimal penggunaanya salah satunya disebabkan oleh kemampuan pendidik dan peserta didik yang terbatas hanya sebagai pengguna, belum mampu berperan sebagai pengelola bahkan pengembangnya. Dari data di lapangan menunjukan hanya sebagian kecil dari pengguna e-learning yang mampu secara konsisten mengelola pembelajaran melalui e-learning. Hal tersebut mengindikasikan kualitas sumber daya manusia di Indonesia belum sepenuhnya siap menggunakan inovasi tersebut.

Namun demikian, sejatinya banyak perguruan tinggi di Indonesia sudah memiliki portal e-learning untuk memfasilitasi pembelajaran, termasuk di Universitas $\mathrm{Ne}$ geri Yogyakarta (UNY). UNY memiliki portal e-learning bernama Besmart. Portal yang berbasis LMS (Learning Management System) ini sudah aktif sejak tahun 2006 dan pada tahun 2015 telah diperbaharui baik dari segi tampilan antar muka maupun fasilitas yang dimiliki. Dengan pembaharuan tersebut, Besmart dapat digunakan untuk memfasilitasi pembelajaran secara synchronous dan asynchronous sekaligus. Namun demikian, UNY sendiri belum menerapkan kebijakan penggunaan Besmart secara penuh 
sebagai pengganti kegiatan tatap muka atau replacement pada setiap matakuliah. Kegiatan pembelajaran secara live synchronous melalui tatap muka masih menjadi komunikasi utama dalam pembelajaran.

Pada Prodi TP FIP UNY sebagian kecil mata kuliah yang sudah konsisten menggunakan E-learning UNY dalam pembelajaran. Berdasarkan pengamatan sebagian besar pemanfaatanya digunakan untuk mendukung aktivitas synchronous, seperti chating online dan sharing materi saja. Beberapa matakuliah seperti Pengembangan E-learning Berbasis Web sudah menerapkan komunikasi asynchronous sebatas forum diskusi, namun kurang konsisten sehingga forum diskusi yang dibentuk menjadi sepi dan pasif. E-learning tersebut, dianggap kurang menarik menurut mahasiswa karena bersifat lebih tertutup karena sulitnya menjalin interaksi multi arah dengan pengguna di luar group. Hal tersebut mengakibatkan interaktivitas pembelajaran menjadi rendah dan terjadi secara tidak maksimal, baik antara pengguna dan sistem, antar pengguna, maupun pengguna dengan konten/materi. Interaktivitas yang rendah mengindikasikan kemampuan belajar mandiri yang rendah pula, sehingga mahasiswa hanya pasif menerima materi dari dosen saja.

Interaktivitas pembelajaran yang rendah pada matakuliah pengembangan $e$ learning berbasis web dapat dilihat dari pasifnya mahasiswa yang ikut berdiskusi. Selain itu, bahan ajar atau materi yang mahasiswa miliki sebatas yang diberikan oleh dosen saja, sehingga hasil belajar terutama saat praktik baik secara mandiri dan kelompok cenderung rendah pula. Dari data hasil belajar pada matakuliah pengembangan e-learning berbasis web tahun 2015, hanya $35 \%$ dari keseluruhan mahasiswa yang mampu mencapai ketuntasan belajar baik dari segi praktek maupun teori, dikarenakan memiliki tingkat interaktivitas yang tinggi. Lebih dari 50\% jumlah mahasiswa belum mampu mencapai ketuntasan belajar secara seimbang antara teori dan praktek.

Mahasiswa yang memiliki kecenderungan aktif, biasanya telah memiliki kete- rampilan verbal yang baik dan bentuk interaksinya masih sebatas antara mahasiswa dan dosen saja. Di sisi lain mahasiswa yang kurang memiliki keterampilan verbal cenderung pasif di kelas. Sejatinya hal tersebut dapat menjadi modal dalam matakuliah tersebut, mahasiswa yang pasif dalam kegiatan tatap muka berpotensi aktif dalam komunikasi asynchronous seperti melalui forum diskusi, apabila diikuti dengan desain pembelajaran online yang menyenangkan. Komunikasi synchronous sendiri merupakan komunikasi yang dilakukan pada waktu yang sama, sedangkan komunikasi asynchronous berkebalikannya yaitu komunikasi yang dilakukan pada waktu yang berbeda.

Interaktivitas pembelajaran yang tinggi mengindikasikan adanya keterampilan berintekasi sosial, kemampuan belajar mandiri dan membangun pengetahuan sendiri oleh mahasiswa. Toffler (Rosenberg, 2001, p. 3) menjelaskan "the illiterate of the $21^{\text {st }}$ century will not be those who cannot read and write, but those who cannot learn, unlearn, and relearn". Ungkapan tersebut bermakna manusia modern saat ini dianggap melek informasi (literate) apabila mampu belajar mandiri bukan lagi sekedar dapat membaca dan menulis. Kemampuan tersebut mensyaratkan kemampuan pendukung salah satunya kemampuan berkomunikasi dengan baik. Ciri manusia dapat berkomunikasi dengan baik yaitu apabila mampu bertukar informasi menggunakan berbagai media kapanpun dimanapun, serta mampu berperan atau menempatkan dirinya sebagai pengirim atau penerima informasi dalam interaksi sosial. Dalam pembelajaran kemampuan tersebut disebut sebagai interaktivitas pembelajaran, dimana setiap mahasiswa mampu berinteraksi dengan baik dan seimbang dengan sesama pengguna, sistem, dan konten. Dengan interaktivitas pembelajaran yang tinggi maka proses dan hasil pembelajaran menjadi berkualitas dan bermakna.

Menurut Allen (2007) interaktivitas pembelajaran dapat tercipta melalui pengaturan empat komponen yaitu konteks, 
tantangan, kegiatan, dan umpan balik. Empat komponen tersebut dapat dilakukan dengan mengaktifkan fitur-fitur yang mendukung komunikasi asynchronous dalam Besmart UNY diantaranya forum diskusi online, lesson, external tool, dan workshop, ditambah dengan fasilitas lain di luar Besmart UNY seperti e-mail, blog dan website hingga sosial media. Penggunaan fitur-fitur tersebut diharapkan mahasiswa menjadi lebih aktif tidak hanya saat pembelajaran tatap muka, akan tetapi pada saat pembelajaran asynchronous atau beda waktu.

Pena, Martin, \& Gay (2001) menjelaskan interaktivitas sebagai kegiatan diskusi untuk bertanya dan menjawab pertanyaan, secara bersama-sama mendukung dan mengklarifikasi ide-ide serta membangun kesepakatan dalam berinteraksi sosial. Sedangkan Vrasidas \& McIsaac (Dabbagh \& Bannan-Ritland, 2005, pp. 80-83) mendefinisikan interaktivitas sebagai "reciprocal actions of two or more actors within a given context". Kedua pengertian tersebut menjelaskan bahwa interaktivitas adalah kuantitas atau banyaknya partisipasi yang terjalin antar subjek untuk mencapai tujuan masing-masing dan tujuan interaksi tersebut.

Sejalan dengan mutual discourse dari Jancowski \& Hanssen, McMillan (2006, pp. 205-229) membagi interaktivitas dalam tiga bentuk yaitu: (1) user to system: interaktivitas jenis ini merupakan komunikasi satu arah, di mana interaksi terjadi melalui teknologi web, seperti mengunduh, me-link ke fitur tertentu dan meng-klik, (2) user to user: interaktivitas ini memiliki karakteristik komunikasi dilakukan antar pengguna ataupun antar-pengguna dengan host (pengelola situs) dengan format "kirim dan respon" yang ditemukan dalam pesan singkat, chat, dan forum diskusi. Interaksi antaruser ditunjukkan secara jelas dengan melakukan komunikasi pada new madia ini dengan jalan saling berkaitan dengan pesanpesan yang berhubungan satu sama lain, (3) user to document/content: interaksi kali ini terjadi dalam konstruksi yang terbagi dalam pesan website, seperti bagaimana pengguna berinteraksi dengan suatu web- site dengan cara mem-posting komentar. Interaksi ini melibatkan "penciptaan ulang", konten yang dilakukan oleh host ketika user memposting informasi atau menyajikan informasi yang dapat mengubah isi pesan dari situs tersebut.

Tingginya tingkat interaktivitas pembelajaran menunjukan derajat kemenarikan proses pembelajaran. Sedangkan kemenarikan pelaksanaan pembelajaran dapat terwujud diantaranya melalui kemenarikan penyajian materi, aktivitas pembelajaran yang menantang, media yang merangsang minat dan rasa ingin tahu, sarana dan prasarana yang mendukung proses pembelajaran, dan sebagainya. Dalam matakuliah Pengembangan E-learning Berbasis Web Prodi TP FIP telah memanfaatkan Besmart UNY sebagai e-learning terintegrasi yang selama ini digunakan sebagai suplemen dalam pembelajaran. Penggunaan e-learning tersebut masih digunakan sebatas diseminasi materi kuliah dan pengumpulan tugas saja. Padahal e-learning yang dimiliki oleh UNY sangat powerfull dimanfaatkan dalam pembelajaran.

Hal tersebut dapat dibuktikan dengan adanya fasilitas yang dimiliki oleh Besmart berupa resource dan activity. Resource merupakan bahan atau sumber belajar yang bisa diakses oleh pengguna, sedangkan activity adalah kegiatan belajar yang dilaksanakan oleh user. Saat ini untuk lebih memudahkan pengguna dalam belajar, Besmart telah di-upgrade menjadi V2 (Versi Dua) oleh UNY. Upgrading terlihat dari perbedaan penggunaan versi, interface atau tampilan antar muka, juga fasilitas yang lebih lengkap seperti big blue button untuk melakukan video call secara synchronous, workshop untuk mendukung interaksi dan penilaian antar user, hingga glossary yang bisa dimanfaatkan sebagai kamus istilah. Dengan berbagai fasilitas tersebut memungkinkan pengguna (peserta didik dan pendidik) bertukar informasi kapan saja dan di mana saja dengan komunikasi synchronous dan asynchronous.

Dabbagh \& Bannan-Ritland (2005) menjelaskan komunikasi asynchronous se- 
bagai komunikasi antar-orang untuk mendistribusikan bahan pembelajaran menggunakan akses komputer berjaringan yang bisa dilakukan setiap saat dan di mana saja. Sedangkan Littlejohn \& Pegler (2007, pp. 51-53) menjelaskan komunikasi ini dengan komunikasi yang dilakukan dalam waktu yang berbeda. Interaksi yang terjadi dalam komunikasi ini terjadi antara peserta didik dengan konten, peserta didik dengan pendidik, antarpeserta didik, dan peserta didik dengan grup atau kelompok belajar. Komunikasi ini mendukung peserta didik dalam belajar mandiri dan belajar kelompok sekaligus.

Besmart UNY telah mendukung komunikasi ini melalui aktivitas forum dan massage. Komunikasi ini memiliki beberapa kelebihan seperti yang diungkapkan oleh Littlejohn \& Pegler (2007, p. 53) yaitu rentang waktu yang sangat fleksibel dan memungkinkan peserta didik berkontribusi penuh dalam pembelajaran. Penggunaannya memang tidak dilakukan dalam kegiatan tatap muka, sehingga komunikasi tersebut tepat bila terintegrasi antara Besmart dengan tools e-learning lainnya. Besmart UNY merupakan e-learning yang dikembangkan menggunakan LMS (Learning Management System) sehingga memiliki tujuan untuk mengelola kegiatan pembelajaran secara online.

E-learning sendiri didefinisikan oleh ILRT of Bristol University yang dijelaskan oleh Surjono (2013, p. 2) sebagai penggunaan teknologi elektronik untuk mengirim, mendukung, dan meningkatkan pengajaran, pembelajaran dan penilaian. Fleksibilitas merupakan ciri dari pembelajaran elektronik ini, sehingga penggunaan komunikasi asynchronous yang terintegrasi dengan pembelajaran elektronik menjadi tepat sasaran dan terarah. Lebih lanjut Surjono (2013, p. 4) menjelaskan fleksibilitas pembelajaran yang terjadi dalam pemilihan waktu dan tempat belajar, karena peserta didik tidak harus dating di suatu tempat dalam waktu tertentu. Wahyuningsih \& Budiningsih (2014, p. 20) menjelaskan penggunaan komunikasi asynchronous juga men- dukung terciptanya pembelajaran campuran atau yang dikenal dengan blended learning.

Melalui komunikasi tersebut interaktivitas pembelajaran dapat tercermin dalam pembelajaran online. Menurut Allen (2015) Interaktivitas pembelajaran, bila dilakukan dengan benar, memotivasi peserta didik untuk berpikir, menganalisis, merenung, dan belajar secara efektif, sehingga sangat penting hal tersebut dirancang dengan benar. Dalam matakuliah pengembangan e-learning berbasis web pada mahasiswa Prodi TP FIP UNY komunikasi ini diperlukan untuk meningkatkan interaktivitas pembelajaran, sehingga penguasaan kompetensi berupa teori dan praktek dapat tercapai dengan efektif dan efisien. Untuk dapat meningkatkan interaktivitas pembelajaran dalam matakuliah pengembangan $e$ learning berbasis web, metode primer yang digunakan untuk menerapkan komunikasi ini dengan menggunakan fasilitas forum diskusi online dalam Besmart UNY.

\section{Metode}

Penelitian ini menggunakan jenis penelitian tindakan kelas, yang bertujuan untuk meningkatkan interaktivitas pembelajaran pada mata kuliah pengembangan $e$ learning berbasis web. Penelitian ini mengacu pada desain penelitian spiral dari Kemmis \& McTaggart (1990, p. 11), berupa empat langkah kesatuan berulang yaitu plan (perencanaan), act (pelaksanaan tindakan) dan observe (observasi), serta reflect (refleksi) yang dilakukan secara kolaborasi antara peneliti dan dosen pengampu mata kuliah. Tindakan yang dilakukan untuk mencapai tujuan penelitian adalah menerapkan komunikasi asynchronous sebagai metode pembelajaran pada mata kuliah tersebut.

Penelitian ini dilaksanakan pada mata kuliah pengembangan e-learning berbasis web yang ditempuh mahasiswa Prodi TAPI FIP UNY semester VI. Penelitian dilaksanakan selama proses perkuliahan berlangsung dalam proses pembelajaran online. 
Subjek penelitian ini adalah seluruh mahasiswa yang menempuh mata kuliah $e$ learning berbasis web yang mengambil konsentrasi Teknologi Informasi Pembelajaran berjumlah 32 orang.

Prosedur penelitian tindakan kelas yang dilaksanakan pada siklus pertama dilaksanakan sebagai berikut:

\section{Perencanaan Tindakan}

Tahap perencanaan dilakukan melalui lima kegiatan yaitu, (1) menyusun Satuan Acara Perkuliahan (SAP) pada topik "Pemanfaatan E-learning dalam Pembelajaran"; (2) mengaktifkan Besmart beserta fitur lesson, assignment, dan forum untuk melaksanakan perkuliahan online melalui komunikasi asynchronous; (3) menyiapkan materi dan sumber belajar pada topik tersebut dalam bentuk e-book, artikel jurnal, buku teks, dan slide power point. (4) menyiapkan skema penugasan yang harus dikerjakan oleh mahasiswa sebagai tugas proyek; (5) menyiapkan checklist sebagai panduan dokumentasi terhadap pelaksanaan pembelajaran online dengan penggunaan komunikasi asynchronous dan pedoman wawancara kepada mahasiswa.

\section{Pelaksanaan Tindakan dan Pengamatan}

Tahap ini dilaksanakan melalui tujuh kegiatan yaitu, (1) memberikan penjelasan sekilas tentang materi "Pemanfaatan E-learning dalam Pembelajaran" dalam pembelajaran tatap muka dan mempersilahkan mahasiswa untuk mengakses Besmart dan mengikuti perkuliahan secara online; (2) memberikan kesempatan kepada mahasiswa untuk mengeksplorasi materi secara individu melalui pembelajaran online dan melaporkan hasil temuannya melalui komunikasi asynchronous; (3) memberikan penjelasan proyek yang harus dikerjakan oleh mahasiswa secara individu. Mahasiswa diminta membuat suatu konten pembelajaran yang diposting melalui knowledge network dan knowledge portal yang sudah disepakati bersama pada pembelajaran tatap muka; (4) memberikan bimbingan, ma- sukan dan saran kepada mahasiswa dalam menyusun tugas proyeknya melalui komunikasi asynchronous; (5) melakukan pemantauan secara berkala baik dalam perkuliahan tatap muka dan online terhadap tugas proyek yang dikerjakan mahasiswa; (6) memberikan penilaian terhadap tugas yang telah dikerjakan mahasiswa; (7) mengamati setiap aktivitas pembelajaran yang dikerjakan mahasiswa melalui Besmart, Email, Watsapp, Instagram, Google+, dan lainlain.

\section{Refleksi}

Dari hasil pelaksanaan tindakan dan pengamatan yang telah dilakukan pada siklus 1 serta hasil diskusi antara peneliti dengan dosen pengampu mata kuliah, maka tampak peningkatan interaktivitas pembelajaran yang diinginkan. Hal tersebut dilihat dari hasil pelacakan dokumen tentang: Interaksi user to system, Interaksi user to user, Interaksi user to document. Siklus 2 akan dilakukan apabila hasil refleksi siklus 1 belum tercapai dan dengan dilakukan perbaikan-perbaikan dalam penerapannya.

\section{Teknik Pengumpulan Data}

Teknik pengumpulan data yang digunakan dalam penelitian ini adalah wawancara, check list, dan dokumentasi. Dokumentasi dilakukan melalui proses tracking atau rekam jejak pada pembelajaran online melalui komunikasi asynchronous. Wawancara digunakan untuk mendukung dan menguatkan data dokumentasi. Wawancara dilakukan oleh peneliti dengan beberapa mahasiswa yang dapat memberikan informasi terkait peningkatan interaktivitas pembelajaran pada perkuliahan.

\section{Teknik Analisis Data}

Teknik Analisis Data yang digunakan adalah deskriptif. Hasil penilaian berupa skor pencapaian interaktivitas pembelajaran kemudian dikonversi ke dalam tabel pedoman konversi nilai interaktivitas pembelajaran yang diadaptasi dari Widoyoko (2012, p. 110) dan disajikan pada Tabel 1. 
Tabel 1. Pedoman Konversi Nilai Interaktivitas Pembelajaran

\begin{tabular}{ccc}
\hline Rentang Nilai & Rentang $\%$ & Kategori \\
\hline $13 \leq x \leq 22,75$ & $25,00 \%-43,75 \%$ & Sangat Rendah \\
$22,76 \leq x \leq 32,50$ & $43,76 \%-62,50 \%$ & Rendah \\
$32,51 \leq x \leq 42,25$ & $62,51 \%-81,50 \%$ & Tinggi \\
$42,26 \leq x \leq 52$ & $81,51 \%-100 \%$ & Sangat Tinggi \\
\hline
\end{tabular}

Indikator Keberhasilan

Penelitian tindakan kelas ini dianggap berhasil ketika interaktivitas pembelajaran dapat meningkat melalui penggunaan komunikasi asynchronous dalam perkuliahan. Peningkatan interaktivitas pembelajaran tersebut harus mencapai kategori tinggi, baik pada setiap indikatornya maupun rata-rata secara keseluruhan yaitu berada pada kategori tinggi pada rentang $32,51 \leq x$ $\leq 42,25$ dengan persentase $62,51 \%-81,50 \%$.

\section{Hasil dan Pembahasan}

Deskripsi hasil penelitian memaparkan secara keseluruhan interaktivitas pembelajaran pada perkuliahan pengembangan e-learning berbasis web dengan penerapan komunikasi asynchronous, mulai kondisi awal, siklus 1 dan siklus 2. Hal tersebut akan disajikan pada urian sebagai berikut:

Secara keseluruhan persentase interaktivitas pembelajaran sebelum tindakan diterapkan yaitu 35\% atau pada kategori sangat rendah.

\section{Siklus 1}

Siklus dilaksanakan pada akhir April hingga awal Mei 2016 selama dua minggu perkuliahan online pada topik pemanfaatan e-learning dalam pembelajaran. Secara spesifik penelitian ini hanya mengukur pencapaian tingkat interaktivitas pembelajaran bukan pada hasil belajar secara keseluruhan. Setelah diterapkan tindakan berupa komunikasi asynchronous pada siklus 1 interaktivitas pembelajaran masih berapa pada kategori rendah dengan skor 31,21 dan berada pada persentase
$60 \%$, penjabaran pada tiap indikatornya disajikan pada Tabel 2.

Tabel 2. Interaktivitas Pembelajaran Siklus 1

\begin{tabular}{ccccc}
\hline No & \multicolumn{1}{c}{ Indikator } & Skor & $\%$ & Kategori \\
\hline 1. & User to system & 15,53 & $64,7 \%$ & Tinggi \\
2. & User to user & 7,09 & $59,1 \%$ & Rendah \\
3. & User to document & 8,59 & $53,7 \%$ & Rendah \\
\hline
\end{tabular}

Penerapan komunikasi asynchronous pada siklus 1 dilakukan pada saat pembelajaran online berlangsung melalui Besmart UNY versi 2. Fitur pada Besmart yang diterapkan untuk mendukung bentuk komunikasi tersebut antara lain forum, assignment, file dan lesson. Forum dan assignmen merukan kelompok activity dalam sistem Besmart, artinya memungkinkan terjadi interaksi multi arah. Forum merupakan fitur pada Besmart untuk melakukan diskusi kelompok dengan user yang sama-sama tergabung dalam sistem dan pada pembelajaran yang sama. Assignment merupakan fitur yang digunakan user untuk mengumpulkan portofolio berupa tugas atau proyek. Komunikasi yang terjalin pada fitur ini hanya dapat dilakukan oleh peserta didik dengan pendidik atau asisten pendidik yang tergabung dalam satu pembelajaran dan sistem yang sama. File dan Lesson merupakan bentuk resource pada Besmart yang tidak memungkinkan komunikasi dua arah atau multi arah. Kedua fitur tersebut berfungsi untuk memberikan instruksi atau upload dan download sumber belajar dengan berbagai format seperti .doc, .pdf, .xls, .jpg, .png, rar, dan lain-lain.

Selain penerapan komunikasi asynchronous yang terintegrasi melalui sistem $e$ learning yang dimiliki oleh UNY yaitu Besmart, pembelajaran juga dilakukan melalui knowledge network lainnya seperti kompasiana, kaskus, instagram, e-mail, serta media sosial seperti facebook, twitter, whatsapp, dan google+. Pembelajaran online yang diterapkan pada siklus 1 belum terjadwal secara khusus sehingga komunikasi asynchronous yang dilakukan juga tidak teratur. Selama dua minggu pelaksana- 
an tindakan, bimbingan dan diskusi materi lebih banyak dilakukan di hari-hari akhir pengumpulan tugas.

Pencapaian indikator user to system pada interaktivitas pembelajaran sudah mencapai kategori tinggi pada siklus 1 , namun penerapannya kurang maksimal. Hal tersebut dikarenakan pelaksanaan komunikasi asynchronous tidak terjadwal rutin seperti pada pelaksanaan pembelajaran tatap muka. Minimnya fitur pada Besmart yang diaktifasi untuk menerapkan komunikasi asynchronous juga ikut menjadi alasan. Penggunaan sosial media yang tidak fokus membahas seputar konten pembelajaran. Indikator user to system dapat mencapai kategori tinggi pada siklus ini, karena mahasiswa yang menempuh mata kuliah pengembangan e-learning berbasis web di Prodi TP sudah familiar menggunakan TIK, sehingga karakteristiknya sesuai dengan metode yang diterapkan. Namun, motivasi dan kultur akademik yang kurang mendukung penerapan komunikasi asynchronous dalam pembelajaran menjadi penghambatnya.

Pencapaian indikator user to user pada siklus 1 masih berada pada kategori rendah. Hal tersebut disebabkan tugas proyek yang dikerjakan mahasiswa disusun secara individu, sehingga meminimalkan interaksi dalam kelompok. Interaksi dengan pendidik pada indikator ini sangat minim terkait konten, sebagian besar interaksi yang terjadi terkait hal-hal teknik tugas. Sedangkan pencapaian indikator user to document pada siklus ini juga masih berapa pada kategori rendah. Hal tersebut diakibatkan penggunaan portal online untuk menerapkan komunikasi asynchronous tidak fokus untuk melakukan kegiatan pembelajaran, seperti penggunaan sosial media. Penggunaan sosial media dalam kegiatan pembelajaran membuat banyak mahasiswa tidak fokus pada konten pembelajaran dan lebih banyak melakukan kegiatan rekreatif pada portal tersebut. Mengingat interaktivitas pada siklus 1 ini masih berada pada kategori rendah maka perlu dilanjutkan pada siklus 2 dengan dilakukan perbaikanperbaikan.
Siklus 2

\section{Perencanaan Tindakan}

Perencanaan tindakan pada siklus 2 meliputi:

a. Menyusun dan memperbarui SAP (Satuan Acara Perkuliahan) pada topik "LMS (Learning Management System)" yang dilaksanakan selama dua kali pertemuan tatap muka dan tiga minggu perkuliahan online.

b. Mengaktifkan Besmart beserta fitur lesson, assignment, forum, wiki, chating, SCROM package, glosary dan workshop untuk melaksanakan perkuliahan online melalui komunikasi asynchronous.

c. Menyiapkan materi dan sumber belajar pada topik tersebut dalam bentuk ebook, buku teks, tutorial di youtube dan website moodle, serta slide power point.

d. Menyiapkan skema penugasan yang harus dikerjakan oleh mahasiswa sebagai tugas proyek.

e. Menyiapkan checklist sebagai panduan dokumentasi terhadapat pelaksanaan pembelajaran online dengan penggunaan komunikasi asynchronous dan pedoman wawancara kepada mahasiswa.

\section{Pelaksanaan Tindakan dan Pengamatan}

Pelaksanaan tindakan dan pengamatan pada tindakan pada siklus 2 meliputi:

a. Memberikan kesempatan kepada mahasiswa terlebih dahulu untuk mengeksplorasi materi secara individu melalui pembelajaran online tentang materi "LMS" dan meminta mahasiswa untuk melaporkannya melalui Besmart.

b. Menanggapi hasil eksplorasi materi dan hasilnya yang di unggah mahasiswa pada laman Besmart yang telah disepakati.

c. Mempersilahkan mahasiswa untuk melanjutkan diskusi mengenai topik melalui komunikasi asynchronous melalui laman Besmart.

d. Memberikan penjelasan proyek yang harus disusun oleh mahasiswa secara berkelompok (kelompok kecil) berupa pe- 
ngembangan LMS pada suatu institusi berdasarkan hasil analisis kebutuhan.

e. Memberikan bimbingan terstruktur dan berkala pada mahasiswa melalui komunikasi asynchronous pada Besmart agar mahasiswa mampu menyelesaikan proyek dengan baik dan tepat waktu.

f. Melakukan pemantauan secara berkala baik dalam perkuliahan tatap muka dan online menggunakan komunikasi asynchronous terhadap tugas proyek yang dikerjakan mahasiswa.

g. Memberikan penilaian terhadap tugas yang telah dikerjakan mahasiswa.

h. Mengamati setiap aktivitas pembelajaran yang dikerjakan mahasiswa melalui sistem Besmart.

Siklus 2 dilaksanakan pada akhir Mei hingga awal Juni 2016 dengan waktu yang berbeda dengan siklus 1 yaitu tiga minggu perkuliahan online. Secara keseluruhan pencapaian interaktivitas pembelajaran pada siklus ini telah mencapai target dengan kategori sangat tinggi dengan skor 42,81 dan persentase $82,33 \%$. Penjabaran tiap indikatornya disajikan pada Tabel 3.

Tabel 3. Interaktivitas Pembelajaran Siklus 2

\begin{tabular}{ccccc}
\hline No & Indikator & Skor & $\%$ & Kategori \\
\hline 1. & User to system & 20,34 & $84,7 \%$ & Sangat Tinggi \\
2. & User to user & 9,84 & $82 \%$ & Sangat Tinggi \\
3. & User to document & 12,63 & $78,9 \%$ & Tinggi \\
\hline
\end{tabular}

Refleksi

Dari hasil pelaksanaan tindakan dan pengamatan yang telah dilakukan pada siklus 2 serta hasil diskusi antara peneliti dengan dosen pengampu mata kuliah tampak adanya peningkatan interaktivitas pembelajaran. Interaktivitas pembelajaran secara keseluruhan juga sudah mencapai target yang ditetapkan. Sehingga pelaksanaan tindakan pada penelitian ini diakhiri pada siklus 2 .

Pembahasan

Dalam 2 siklus tindakan, peningkatan interaktivitas pembelajaran melalui penggunaan komunikasi asynchronous dapat tercapai dengan kategori sangat tinggi pada perkuliahan pengembangan e-learning berbasis web. Tiga indikator interaktivitas pembelajaran yaitu user to system, user to user, dan user to document menunjukan peningkatan yang beriringan. Tiap indikatornya dijabarkan sebagai berikut:

\section{User to System}

Peningkatan interaktivitas pembelajaran yang ditunjukan oleh aspek user to system sudah berada pada kategori tinggi pada siklus 1 dan sangat tinggi pada siklus 2. Rata-rata skor dari 6 butir indikator yang diperoleh pada aspek ini yaitu 15,53 pada siklus 1 dan 20,34 pada siklus 2. Terdapat tiga hal yang mempengaruhinya yaitu, a) habit operation terhadapat TIK yang sudah dimiliki mahasiswa sebelum mengikuti perkuliahan, (b) feedback dari interaksi yang dapat diprediksi oleh mahasiswa karena interaksi dilakukan dengan mesin (man machine interaction), (c) adanya konsisten tindakan yang dilakukan.

Faktor pertama yaitu adanya habit operation terhadapat teknologi informasi dan komunikasi yang sudah dikuasasi dengan baik oleh mahasiswa dapat mendukung penggunaan komunikasi asynchronous pada perkuliahan. Mahasiswa yang sudah terbiasa mengakses dan menggunaan portal online dapat dengan baik menggunakan analoginya pada portal pembelajaran. Rata-rata pencapaian skor pada siklus 1 dan siklus 2 berturut-turut adalah 15,53 dan 20,34 telah membuktikan karakteristik mahasiswa yang ada pada perkuliahan $e$ learning berbasis web siap dan mampu menggunakan komunikasi asyncronous dengan sangat baik.

Faktor keberhasilan yang kedua yaitu adanya interaksi dengan mesin yang membuat umpan balik mudah diprediksi oleh mahasiswa. Setiap tindakan atau aksi yang dilakukan oleh mahasiswa dalam berinteraktivitas melalui sistem e-learning dapat dilakukan dengan baik. Namun hal tersebut juga tergantung pada instruksi atau penjalasan yang sudah diberikan sebelum- 
nya oleh dosen. Faktor selanjutnya adalah konsistensi tindakan. Hal ini erat kaitanya dengan motivasi yang dimiliki oleh mahasiswa untuk belajar dan berdiskusi melalui mode komunikasi asynchronous. Motivasi instrinsik ini muncul karena komunikasi asynchronous dilakukan melalui sistem yang sudah banyak digemari baik karena tampilan maupun fungsionalitasnya, serta sistem yang memiliki gengsi tinggi, seperti e-learning universitas seperti Besmart, portal pembelajaran yang terkenal seperti Kompasiana, Kaskus, Academia Edu.

User to User

Rata-rata skor peningkatan interaktivitas pembelajaran pada aspek user to user berturut-turut pada siklus 1 dan siklus 2 yaitu 7,07 dan 9,84. Pada siklus 1 aspek ini berada pada kategori rendah sendang pada siklus 2 berada pada kategori sangat tinggi. Peningkatan rerata skor pada aspek tersebut dari siklus 1 dan siklus 2 cukup tinggi dikarenakan kegiatan pembelajaran lebih banyak dilakukan secara kolaborasi dalam kelompok-kelompok kecil. Pembelajaran lebih dimaknai sebagai proses sosial dengan interaksi multi arah, sehingga mutual discourse benar-benar tercipta. Mahasiswa tidak hanya berinteraksi dengan rekan sesama mahasiswa dalam satu kelas, akan tetapi interaksi juga terjadi dengan rekan di luar, dosen, dan pakar. Adanya kolaborasi sangat mendukung aspek user to user dalam komunikasi ini. Hal tersebut seperti dijelaskan oleh Wahyuningsih \& Budiningsih (2014, p. 23) bahwa melalui aktivitas collaborative asynchronous antar user dapat bertukar pikiran terutama ketika pada hal yang memerlukankan penyelesaian masalah.

\section{User to Document}

Rerata skor interaktivitas pembelajaran pada aspek user to document berturut-turut pada siklus 1 dan silus 2 yaitu 8,59 dan 12,63. Pada siklus 1 aspek ini berada pada kategori rendah dan meningkat pada siklus 2 pada kategori sangat tinggi. Hal tersebut disebabkan oleh dua faktor, yaitu: (a) terpadunya sistem e-learning yang digunakan dalam pelaksanaan pembelajaran online sebagai tempat di mana komunikasi asynchronous diterapkan sehingga mahasiswa fokus belajar mengenai topik yang dibahas, dan (b) keberagaman penerapan aktivitas pada sistem tersebut yang menjadikan komunikasi asynchronous, sebagai mode utama dalam berinteraksi.

Penggunaan jenis portal pembelajaran ternyata mempengaruhi aktivitas pembelajaran yang dilakukan oleh mahasiswa. Semakin terpadu dan terintegrasinya suatu portal atau sistem pembelajaran online, semakin teratur pula pelaksanaan pembelajaranya. Hal tersebut diimbangi dengan penjadwalan aktivitas yang terencana dengan baik dan terbuka antara semua pihak (dosen dan mahasiswa). Penggunaan Besmart sebagai e-learning yang terintegrasi menjadikan seluruh aktivitas pembelajaran terpadu dan satu pintu, sehingga maha-siswa tidak kehilangan arah dalam belajar. Keberagaman resource dan activity yang mendukung komunikasi asynchronous seperti page, URL, forum, wiki, external tool, dan workshop pada Besmart membuat interaktivitas pembelajaran meningkat. Dengan keberagaman aktivitas tersebut, mahasiswa dapat melakukan komunikasi multiara dengan lebih mudah dan tidak membosankan.

\section{Simpulan dan Saran}

Hasil penelitian menunjukkan bahwa meningkatkan interaktivitas pembelajaran melalui penggunaan komukasi asynchronous pada mata kuliah pengembangan e-learning berbasis web di Prodi TP UNY dilakukan melalui 4 hal bahwa komunikasi asynchronous: (1) diterapkan secara konsisten pada mata kuliah e-Learning Berbasis Web, (2) digunakan menancap (embed) pada e-Learning UNY (Besmart), (3) dimanfaatkan untuk menyelesaiakn tugas yang memerlukan kolaborasi, dan (4) menggunakan tipe yang bervariasi.

Interaktivitas pembelajaran dapat ditingkatkan dengan menggunakan komunikasi asynchronous pada mata kuliah pe- 
ngembangan e-learning berbasis web dalam dua siklus. Kondisi awal persentase interaktivitas 35\% kategori sangat rendah meningkat menjadi 31,21 dengan persentase $60 \%$ yang berada pada kategori rendah pada siklus 1. Pada siklus 2 terjadi peningkatan rerata skor interaktivitas pembelajaran menjadi 42,81 dengan persentase $82,33 \%$ yang berada pada kategori sangat tinggi.

Adapun saran yang dapat diberikan untuk baik bagi mahasiswa, dosen, serta pemangku kebijakan dalam penerapan komunikasi asynchronous ini yaitu sebagai berikut. Pertama, mahasiswa perlu membangun keinginan dan motivasi intrinsiknya dalam melakukan pembelajaran multi arah dan bersifat terbuka pada inovasi pada bidang pendidikan dan pembelajaran, khusunya mode pemelajaran jarak jauh secara online yang lebih memanfaatkan teknologi e-Learning dan metode komunikasi asynchronous ini.

Kedua, perlu adanya pembiasaan penggunaan metode ini baik bagi mahasiswa maupun dosen pengampunya, seperti pepatah mengatakan "ala bisa karena biasa". Metode ini dapat digunakan sebagai salah satu mode utama dalam pembelajaran, sehingga kinerja pembelajaran menjadi meningkat. Ketiga, pemangku kebijakan pada level fakultas atau universitas perlu mengakomodasi dan memberikan kesempatan kepada dosen dan mahasiswa untuk dapat melakukan perkuliahan online menggunakan komunikasi asynchronous, agar masalah jarak, waktu, dan kesempatan dapat teratasi.

\section{Daftar Pustaka}

Allen, M. W. (2007). Designing succesful elearnin. USA: Pfeiffer.

Dabbagh, N., \& Bannan-Ritland, B. (2005). Online learning concepts, strategies, and application. New Jersey: Person Education.

Kemmis, S., \& McTaggart, R. (1990). The action research planner. Victoria: Deakin University.
Khan, B. (2005). Managing e-learning: design, delivery, implementattion and evaluation. Hershey, PA: Information Science Publishing.

Littlejohn, A., \& Pegler, C. (2007). Preparing for blended e-learning. New York: Routledge.

Makmur, R. (2016). Bisnis online. Bandung: Informatika.

Maulana, A. (2015). Jumlah pengguna internet Indonesia capai 88,1 juta. Retrieved March 14, 2016, from http://tekno.liputan6.com/read/2197 413/jumlah-pengguna-internetindonesia-capai-881-juta

McMillan, S. J. (2006). Exploring models of interactivity from multiple research traditions: Users, documents and systems. In L. . Lievrow \& S. M. Livingstone (Eds.), Handbook of new media (pp. 205-229). London: Sage.

Pena, S. J., Martin, W., \& Gay, G. (2001). An epistemological framework for analizing student interactions in computer-mediated environments. Journal of Interactive Learning Research, 12(1), 41-68.

Rosenberg, M. J. (2001). E-learning strategies for delivering knowledge in the digital era. New York, NY: McGraw Hill.

Surjono, H. D. (2013). Membangun bourse elearning berbasis Moodle. Yogyakarta: UNY Press.

Wahyuningsih, D., \& Budiningsih, C. A. (2014). Implementasi blended learning by the constructive approach (BLCA) dalam pembelajaran interaksi manusia dan komputer. Jurnal Inovasi Teknologi Pendidikan, 1(1), 15-27.

Retrieved from http://journal.uny.ac.id/index.php/ji tp/article/view/2456

Widoyoko, E. P. (2012). Teknik penyusunan instrumen penelitian. Yogyakarta: Pustaka Pelajar. 